\title{
Effect Of Cloud Accounting As Income Statement On Accountant Performance
}

Author Notification

7 July 2019

Final Revised

22 October 2019

Published

26 December 2019

\footnotetext{
Qurotul Aini ${ }^{1}$, Anoesyirwan ${ }^{2}$, Yuliana ${ }^{3}$

1,3University of Raharja, Jl. Jenderal Sudirman No.40 Modern Cikokol Tangerang

${ }^{2}$ Persada Indonesia Y.A.I University, Jl. Pangeran Diponegoro No.74 Jakarta Pusat e-mail: aini@raharja.info, anoesyirwan@aptisi.or.id, yuliana.yuli@raharja.info
}

To cite this document:

Aini, Q., Anoesyirwan., \& Yuliana. (2019). Effect Of Cloud Accounting As Income Statement On Accountant Performance. Aptisi Transactions On Management (ATM), 4(1), 13-21.

DOI : https://doi.org/10.33050/atm.v4i1.920

\begin{abstract}
A simple and secure security accounting system is a system needed by various large and small companies where of course the company is never separated from accounting in order to process financial expenditures and revenues owned by companies that have a purpose to make a profit. Efforts to achieve success in a company can be seen from financial management which can be monitored and can be managed properly so that finance can be controlled well too, for that accuracy is an important role so with the company's cloud accounting it can be easier to monitor and also manage financial well, so it will be easier to make income / loss statements. cloud accounting provides a user friendly look that can certainly facilitate users. The purpose of this study is so that companies can pay more attention to monitoring and managing finances well so that it can facilitate the making of income statement. In this study took place used observational research methods and field library studies so that the system made can meet the existing needs of the company.
\end{abstract}

Keywords: Accounting System, Company, Income Statement

\section{Introduction}

Technological progress has created all information systems that can spoil consumers so that every job can be easier, especially in the financial sector. At present the accounting information system is no less rapid development with other information systems, it is important to know where large and small companies do not escape accounting which means that an accounting system that has accurate and real time data is needed.

The importance of financial management is that companies can monitor the existing financial expenditures, where the issued capital must be balanced with the income earned. For that reason, accuracy in counting must be an activity that needs to be maintained.

For that reason, accuracy will be more difficult to maintain if there is no system that supports it, then there is cloud accounting in order to facilitate the work of an accounting and other employees because the software designed is flexible which means it can be used according to existing needs.

According to Huang, N. (2016) Accounting cloud has a significant competitive advantage both low costs which can reduce the costs of business, and high efficiency, which can greatly enhance the working efficiency of enterprise financial accounting. yang dimana memiliki arti cloud accounting has a significant competitive advantage in both low costs that can reduce business costs, and high efficiency, which can greatly improve the work efficiency of financial accounting companies.[1] 


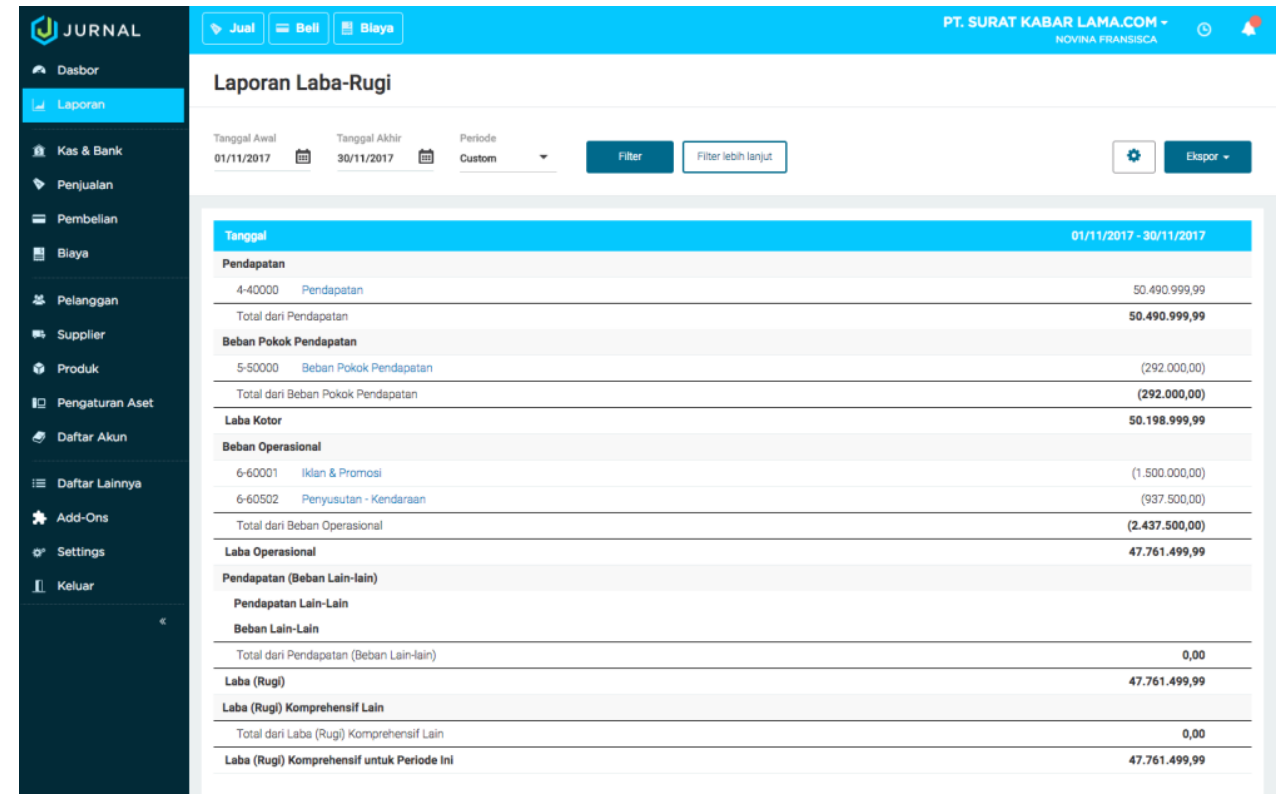

Figure 1. Dashboard Menu Display of income statement

In Figure 1. is a dashboard display of the income statement menu where this view is generated at the time after clicking the "report" menu on the left. This dashboard is used.

\section{Research Method}

During this study, there were several research methods used, namely observation and literature study methods.

\subsection{Method of collecting data}

Data collection in this study using observation, interview, and literature study techniques. Observation techniques are carried out directly by monitoring existing needs.

\subsection{Library study method}

According to Indri handayani, dkk (2018) Library Studies is a method used to collect relevant information in accordance with the topics and problems that are the object of research [2]. In an effort to improve cloud accounting, there are several literature reviews, including:

1. Research conducted by Inova Fitri Siregar, Rinayanti Rasyad, Early Onasis with the title USING ACCOUNTING COMPUTER APPLICATIONS ON THE ACCOUNTANT POWER REQUIREMENTS IN THE COMPANIES IN PEKANBARU CITY (2018) "accounting software helps in saving expenses. Computer Accounting-based accounting applications help employee work. In addition, it also provides convenience in storing data, and helps accelerate the information processing process for management decisions "[3].

2. Research conducted by Untung Rahardja, Qurotul Aini, Marviola Hardini under the title Application of Online Accounting Software as a Financial Reporting Supporting Report (2018) "This study discusses the recording of financial statements which says that the existence of Software Journal (Online Accounting Software) is considered to facilitate accountants in entering transaction data into the system, where the transaction data can be directly imported into the system so that it is more efficient "[4]

3. Based on the journal id website "Income reports that have been processed in such a way are one of the important points that exist in financial terms as a complete condition for making profit and loss" [5]

4. Research conducted by Mokoginta, N., Lambey, L., \& Pontoh, W. (2017). entitled "The Effect of Internal Control Systems and Regional Financial Accounting Systems on the Quality of Government Financial Reports". This study discusses financial statements in which financial statements are a means to provide information used in making economic, social and political decisions and as evidence of accountability and management. [6]

5. This research was conducted by Hoitash, R., Hoitash, U., Kurt, A. C., \& Verdi, R. S. (2018). entitled "An Input-Based Measure of Financial Statement Comparability". This study discusses the compatibility of financial statements which in this article says that the income statement is very useful when estimating income. [7] 
6. Research conducted by Rahardja, U., Aini, Q., and Thalia, MB, (2018), entitled "Application of Confirmation Menu for Yii-Based Online Payment in Higher Education" This study reviews a system in which payment confirmation forms have facilities on Universities with Yii Framework 2 based on CRUD (Create, Read, Update, Delete) feature which has the function of facilitating two parties, namely the cashier and also the students. Then in addition there are 3 (three) advantages that can be produced, namely the first on the menu facility payment confirmation form designed with a website-based so as to facilitate the user in accessing, then the second advantage is that there are several payment method options equipped with the number of payment bills making it easier to make transactions and the third advantage is the availability of an input menu or invoice display so that the data inputted by the user can be guaranteed the truth. [8]

7. This research was conducted by Asatiani, A., \& Penttinen, E. (2015), entitled "Managing the move to the cloud-analyzing the risks and opportunities of cloud-based accounting information systems". This study discusses the cloud - analyzing risks and cloud-based accounting information system opportunities which benefit 3 (three) parties, namely an accountant and client company and auditors who can work simultaneously on data in real time. [9]

8. This research was carried out by Wullur, R. A. M. L., Karamoy, H., \& Pontoh, W. (2016), entitled "Analysis of the Application of Inventory Accounting Based on PSAK No. 14 At PT. Gatraco Indah Manado "this study says that the income statement is the Income Statement (a Statement of Income) is a systematically compiled report about the income and expenses of a company or organization to show a profit or loss for a certain period. [10]

9. This research was conducted by Pitasari, A., \& Septiani, A. (2014), with the title "Analysis of the Influence of Corporate Governance Structure on the Compliance Level of IFRS Convergence Disclosure on Comprehensive Income Statement" This study discusses the comprehensive income statement which is said to report Comprehensive income is a report that is always considered by stakeholders in the annual report as their guidance in making decisions. In addition, the comprehensive income statement also describes the company's performance in one reporting period. [11]

\section{Results and Analysis}

In the company, financial statements are needed in which there is accuracy of the data in order to find information that is informative and the purpose of not experiencing losses is that one of the financial statements used by the company is the Profit / Loss report.

The profit and loss report on cloud accounting displays the movement of the business so that it can find out the total amount of income, and expenses both cost of goods sold and operating costs. Besides that, you can also see gross profit and net profit / loss from the results of the business that has been done.

According to Arofah, U., Astuti, DSP, \& Harimurti, F. (2017), the income statement can be interpreted that when a company experiences a profit it will reduce the audit delay risk and a company that does not profit so the audit risk delay is greater than the company experiencing profit. [12]

In the income statement menu there are two ways to use, namely how to filter reports and also how to custom templates in accordance with what is needed by the company, here is how to use both types of use.

In order to be directed to the income statement menu, click Click Report menu on the Business Overview tab, click "Profit and Loss", then when you want to filter select the period you want to display and click "Filter" to process.

\section{Laba Rugi (dalam IDR)}

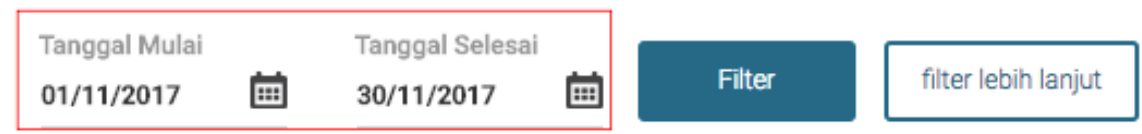

Figure 2. Icon filter 
In Figure 2 the filter icon is displayed and information about filtering based on the start and end dates according to the existing needs which is information about the period from until what date the report will be displayed, for example from 01 November 2017 - 31 November 2017.

However, if you want to filter the report in more detail then click the "More Filter" icon located to the right of the "Fllter" icon.

\section{Laba Rugi (dalam IDR)}

Tanggal Mulai

01/11/2017

\section{Tanggal Selesai \\ 30/11/2017}

\section{Filter}

\section{filter lebih lanjut}

Figure 3. Further Filter Icon

The picture above is an icon that shows that there is an advanced filter which was discussed earlier that the icon is used when the user wants to filter more detail than the "filter" icon.

After clicking on one of the icons above, a pop up page will appear on the right of the dashboard, which provides more detailed information and to ascertain whether the selected data really wants to be filtered or not.

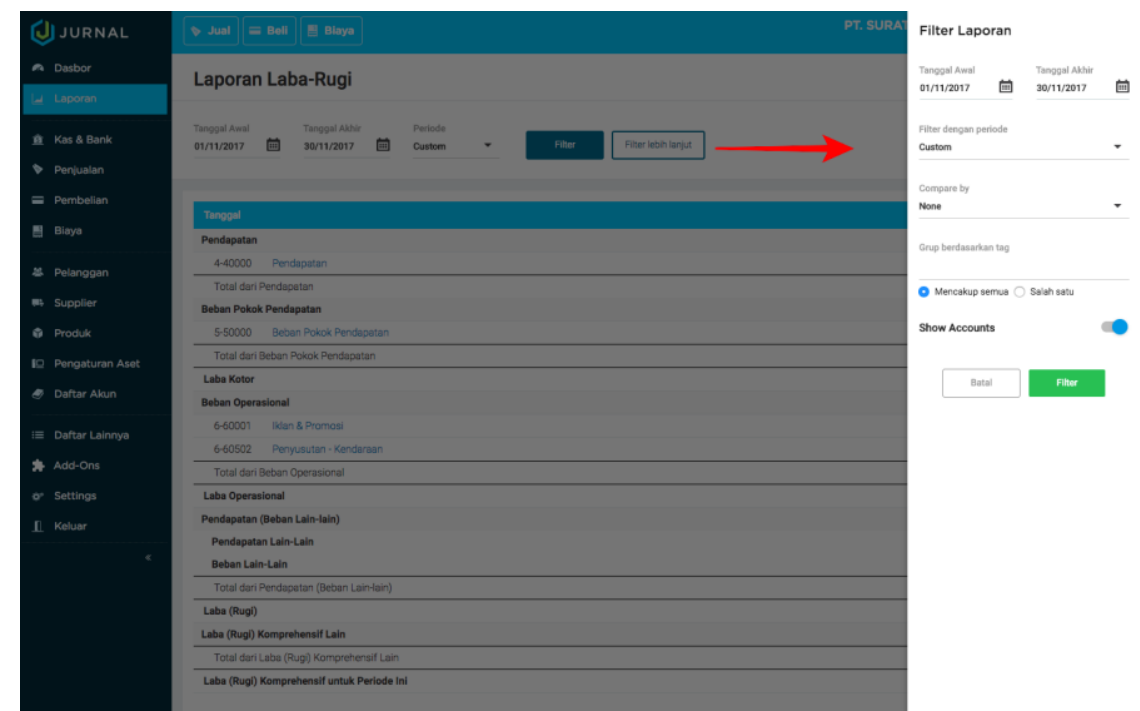

Figure 4. Pop Up page

In Figure 4, a pop up page is displayed where in the Period option, users can display a comparison of reports up to 11 previous periods. Then, it can sort the period based on the beginning to end, or from the end to the beginning. For Tag options, users can display a comparison of the income statement up to a maximum of 5 tags, and there are show accounts that can be swiped to the side to display the report with the names of their accounts. 


\begin{tabular}{|c|c|}
\hline & \\
\hline Tanggal & 01/11/2017 - 30/11/2017 \\
\hline \multicolumn{2}{|l|}{ Pendapatan } \\
\hline 4-40000 Pendapatan & $50.490 .999,99$ \\
\hline Total dari Pendapatan & $50.490 .999,99$ \\
\hline \multicolumn{2}{|l|}{ Beban Pokok Pendapatan } \\
\hline 5-50000 Beban Pokok Pendapatan & $(292.000,00)$ \\
\hline Total dari Beban Pokok Pendapatan & $(292.000,00)$ \\
\hline Laba Kotor & 50.198.999,99 \\
\hline \multicolumn{2}{|l|}{ Beban Operasional } \\
\hline 6-60001 Iklan \& Promosi & $(1.500 .000,00)$ \\
\hline 6-60502 Penyusutan - Kendaraan & $(937.500,00)$ \\
\hline Total dari Beban Operasional & $(2.437 .500,00)$ \\
\hline Laba Operasional & 47.761.499,99 \\
\hline \multicolumn{2}{|l|}{ Pendapatan (Beban Lain-lain) } \\
\hline \multicolumn{2}{|l|}{ Pendapatan Lain-Lain } \\
\hline \multicolumn{2}{|l|}{ Beban Lain-Lain } \\
\hline Total dari Pendapatan (Beban Lain-lain) & 0,00 \\
\hline Laba (Rugi) & 47.761.499,99 \\
\hline \multicolumn{2}{|l|}{ Laba (Rugi) Komprehensif Lain } \\
\hline Total dari Laba (Rugi) Komprehensif Lain & 0,00 \\
\hline Laba (Rugi) Komprehensif untuk Periode Ini & 47.761.499,99 \\
\hline
\end{tabular}

Figure 5. PDF form of income statement

In Figure 5. a profit and loss statement is displayed in PDF form where before the image is displayed, a report is previously exported by clicking the "Export" button and selecting the desired file format. Available formats are PDF, Excel or CSV.

If the user wants to see the income statement by comparison per month in the current year, select this year's report (Monthly). You will see a comparison of earnings per month with percentages.

At the time of making the income statement, also need to know the data that needs to be displayed in accordance with the needs of the company / user by using cloud accounting at this time is the best solution to facilitate the work in analyzing financial management.

There are features provided by cloud accounting in order to custom template income statements as needed.

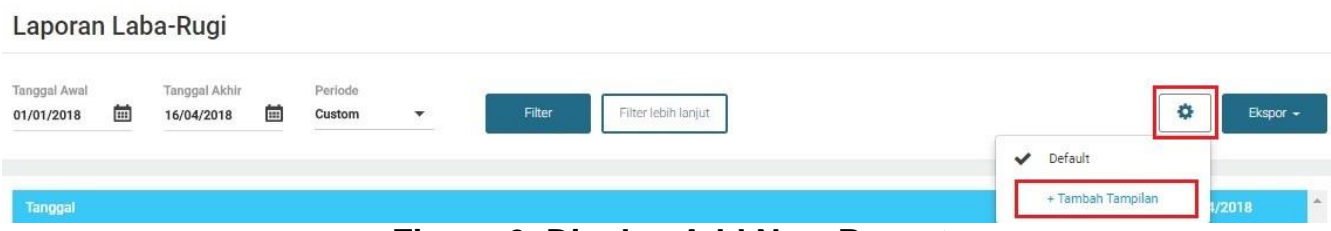

Figure 6. Display Add New Report

In Figure 6. Displayed to add a new, modifiable report that can be done on the settings menu then select + Add Display. 


\section{Laporan Laba-Rugi}

Anda dapat mengkustom tampilan laporan \& mengorder akun.

Nama Layout

Laba Rugi Manajemen Keuangan|

Figure 7. Display Changing the Layout Name

Continued for the name of the layout that you want to display can be changed according to the user's wishes. Then directed to the income statement page which can be changed as follows:

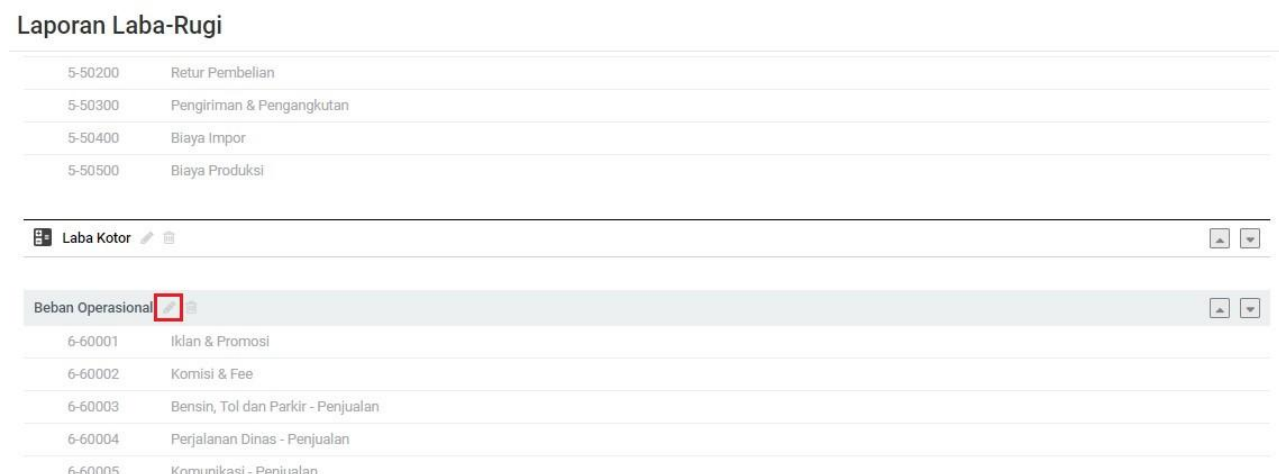

Figure 8. Display of Profit / Loss Report

In Figure 8 it is explained that the income statement can be changed by clicking the pencil icon. Similar to before that all layout names can be edited or can be changed according to the user wants as well as for the category name of the category can be changed like the example below:

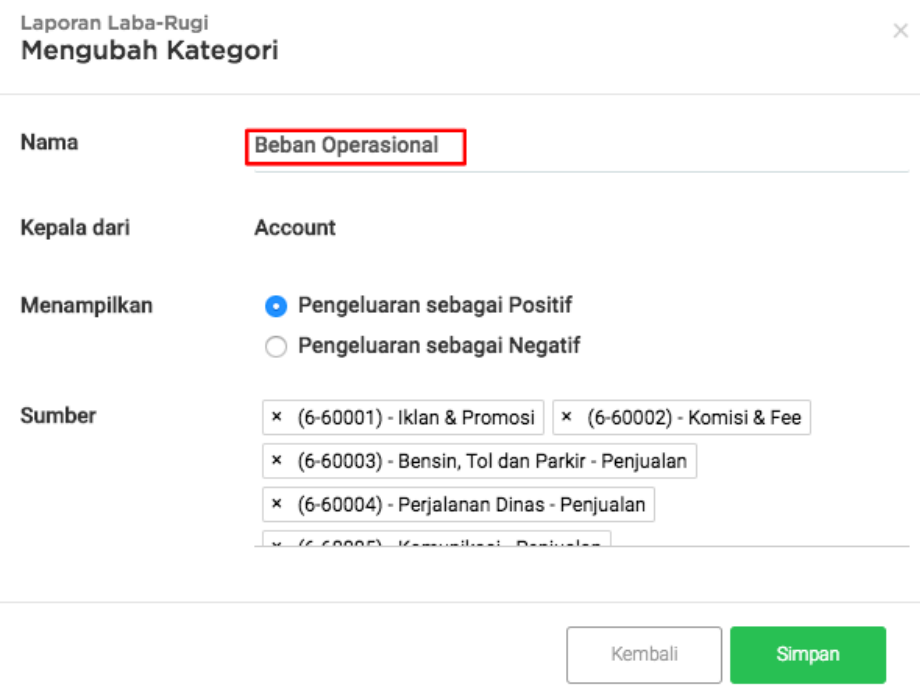

Figure 9. Display Change Category

In Figure 9. Changing the category can be done by changing the name field to the name of the name as desired, if you have typed the name, then make sure that the name of the category is appropriate, then click "SImpan". 
To add a new category Fill in the name of the category, specify this category type as the head of the account or head of the category, specify the display of the load, whether to display a positive or negative number, select the account source and click "Save".

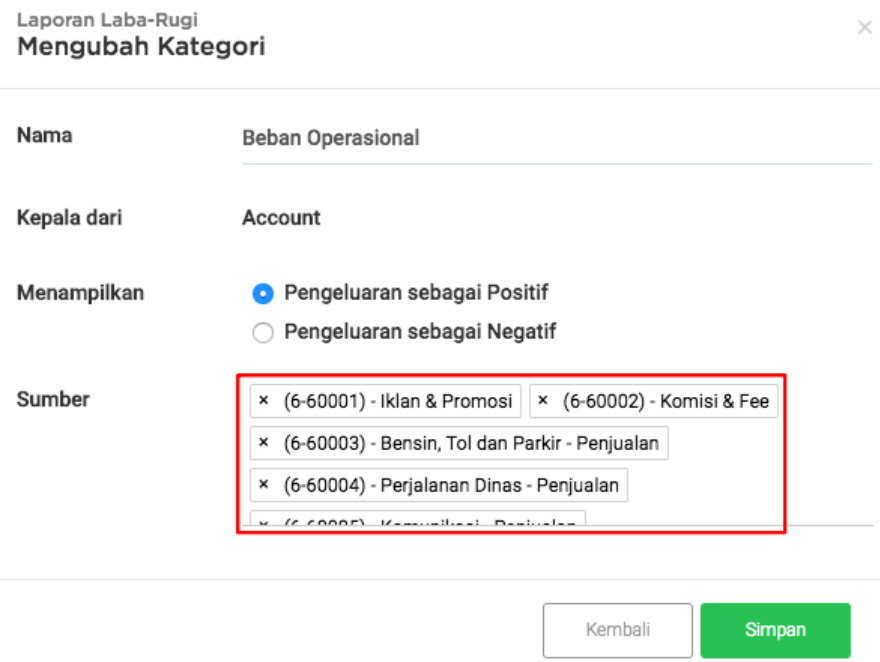

Figure 10. Display of changing sub-accounts

Then it is also important that sub-accounts can be modified from pre-arranged categories, by deleting or adding sub-accounts. In the income statement intended for financial management analysis, it can be done to remove all depreciation expenses from general and administrative expenses as follows, then click "Save".

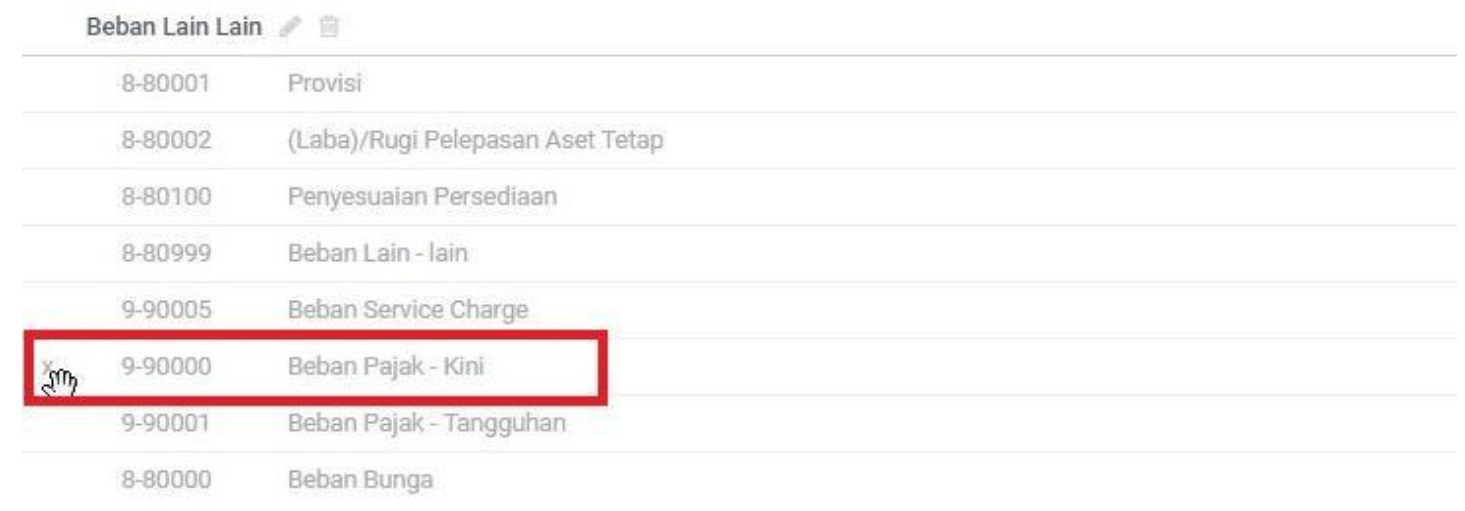

Figure 11. Display Deleting a sub account

In Figure 10, the researcher explains that if a sub-account in the income statement has been made beforehand an error occurs, then the action that must be done is to delete. So the accountant at the company can do the facility to delete the sub with the initial step, which is to select the "X" symbol. In addition, when there is an error on the category label, it can use the features found in cloud accounting by clicking the button, so that the user does not need to worry if an error occurs because of the available features that can overcome. 


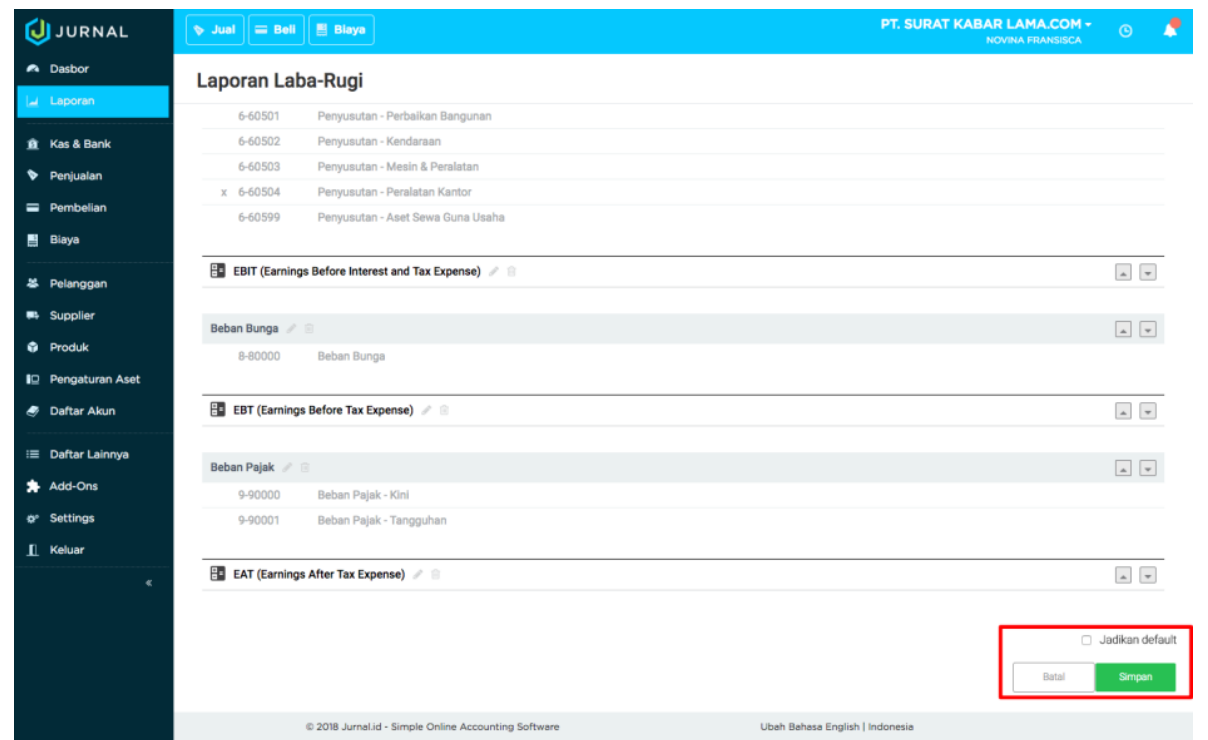

Figure 12. Display of income statement template

As previously discussed, this custom template is provided so that accountants can easily complete their work easily and quickly, therefore this cloud accounting also provides that the template that was created can be used as a default template. By clicking "Make Default" and clicking "Save".

\section{Conclusion}

Based on the research discussed above regarding cloud accounting, it has been proven that cloud accounting makes it easy for an accountant to complete his work specifically to complete an income statement in which the template can be customized according to the needs of the company. where if an error occurs the feature can be used. Moreover, cloud accounting can be accessed online so it can be easier to use.

\section{References}

[1] Huang, N. (2016). Discussion on the Application of Cloud Accounting in Enterprise Accounting Informatization. In 2nd International Conference on Economics, Social Science, Arts, Education and Management Engineering (ESSAEME 2016), Published by Atlantis Press (pp. 136-139).

[2] Handayani, I., Febriyanto, E., \& Bachri, E. W. (2018). Aplikasi Stat Counter Sebagai Alat Monitoring Aktivitas Website PESSTA+ Pada Perguruan Tinggi Raharja. SISFOTENIKA, 8(2), 188-197.

[3] Siregar, I. F., Rasyad, R., \& Onasis, D. (2018). PENGGUNAAN APLIKASI KOMPUTER AKUNTANSI TERHADAP KEBUTUHAN TENAGA AKUNTAN PADA PERUSAHAAN DIKOTA PEKANBARU.

[4] Rahardja, U., Aini, Q., \& Hardini, M. (2018). PENERAPAN cloud accounting SEBAGAI PENUNJANG PENCATATAN LAPORAN KEUANGAN. SISFOTENIKA, 8(2), 176-187.

[5] Jurnal, "Menu Home“, https://www.jurnal.id/id diakses tgl 9 Maret 2017.

[6] Mokoginta, N., Lambey, L., \& Pontoh, W. (2017). PENGARUH SISTEM PENGENDALIAN INTERN DAN SISTEM AKUNTANSI KEUANGAN DAERAH TERHADAP KUALITAS LAPORAN KEUANGAN PEMERINTAH. Jurnal Riset Akuntansi Going Concern, 12(2).

[7] Hoitash, R., Hoitash, U., Kurt, A. C., \& Verdi, R. S. (2018). An Input-Based Measure of Financial Statement Comparability.

[8] Rahardja, U., Aini, Q., \& Thalia, M. B. (2018). Penerapan Menu Konfirmasi Pembayaran Online Berbasis Yii pada Perguruan Tinggi. Creative Information Technology Journal, 4(3), 174-185.

[9] Asatiani, A., \& Penttinen, E. (2015). Managing the move to the cloud-analyzing the risks and opportunities of cloud-based accounting information systems. Journal of Information Technology Teaching Cases, 5(1), 27-34.

[10] Wullur, R. A. M. L., Karamoy, H., \& Pontoh, W. (2016). Analisis Penerapan Akuntansi Persediaan Berdasarkan PSAK No. 14 Pada PT. Gatraco Indah Manado. Jurnal Riset Akuntansi Going Concern, 11(1). 
[11] Pitasari, A., \& Septiani, A. (2014). Analisis Pengaruh Struktur Corporate Governance Terhadap Tingkat Kepatuhan Pengungkapan Konvergensi IFRS Pada Laporan Laba Rugi Komprehensif. Diponegoro Journal of Accounting, 3(2), 132-140.

[12] Arofah, U., Astuti, D. S. P., \& Harimurti, F. (2017). UKURAN PERUSAHAAN SEBAGAI PEMODERASI PENGARUH KEPEMILIKAN PUBLIK KOMITE AUDIT DAN LABA RUGI TERHADAP AUDIT DELAY. Akuntansi, 13(2).

[13] Rahardja, U., Aini, Q., \& Hardini, M. (2018). PENERAPAN SOFTWARE AKUNTANSI ONLINE SEBAGAI PENUNJANG PENCATATAN LAPORAN KEUANGAN. SISFOTENIKA, 8(2), 176187.

[14] Sunarya, A., Saptoro, A., \& Apriyani, D. (2017). Utilization Setting Menu To Build Company Accounting System In Web Based Accounting Online System. Aptisi Transactions of Management (ATM), 1(1), 1-10.

[15] Aisyah, E. S. N., Maimunah, M., \& Martono, A. (2017). Effectiveness of Book Closing Using Web Based Accounting Online System 2.0 to Know the Company's Financial Ratios. Aptisi Transactions of Management (ATM), 1(1), 60-65.

[16] Supriati, R., Aryani, D., \& Maesaroh, S. (2017). Asset Management Using a Web-Based Accounting Online System To Maintain Value of Company Assets. Aptisi Transactions of Management (ATM), 1(1), 34-41.

[17] Sunarya, P. A., Nurhaeni, T., \& Haris, H. (2017). Bank Reconciliation Process Efficiency Using Online Web Based Accounting System 2.0 in Companies. Aptisi Transactions of Management (ATM), 1(2), 131-136.

[18] Martono, A., \& Maesaroh, S. (2017). Utilizing Customer List Menu To Monitoring Customer Data On Web Based Accounting Online System 2.0. Aptisi Transactions of Management (ATM), 1(2), 101-109.

[19] Manurung, E. B. P., Ariessanti, H. D., \& Desrianti, D. I. (2017). Implementation of Recording System Regular Spending Cost Based Software Online Accounting For Record Expenditures on the Company. Aptisi Transactions of Management (ATM), 1(2), 123-130.

[20] Azizah, N., Suryana, E., \& Haris, H. (2017). Application of a Customer Based Data Monitoring Facility Online Accounting Software For Effectiveness Leadership at Higher Education. Aptisi Transactions of Management (ATM), 1(2), 93-100.

[21] Suryana, E., Syafnidawati, S., \& Aryani, D. (2017). Utilization Chart of Account For Effectiveness Company Cash Mapping On Web Based Accounting Online System 2.0. Aptisi Transactions of Management (ATM), 1(1), 27-33.

[22] Djatmiko, B., \& Husain, A. (2017). Analyze and Record a Series of Corporate Sales Transactions On Web Based Accounting Online System. Aptisi Transactions of Management (ATM), 1(2), 110-122.

[23] Rahardja, U., Harahap, E. P., \& Dewi, S. R. (2019). The Strategy of Enhancing Article Citation and $\mathrm{H}$-Index on SINTA to Improve Tertiary Reputation. TELKOMNIKA (Telecommunication Computing Electronics and Control), 17(1). 